\title{
超音波ガイド下中心静脈バスキュラーアクセス穿刺訓練における シミュレーション医学の応用
}

\author{
鎌 田 正 ${ }^{1}$ 落合 美由希 ${ }^{1}$ 藤澤 奈 央 ${ }^{1} \quad \mathrm{~F}^{\text {屋 佑 子 }}$ \\ 富田 真 ${ }^{1}$ 岡 村 基 弘 $^{2}$ \\ 京都市立病院腎臟内科 ${ }^{1}$ 岡村医院 ${ }^{2}$
}

キーワード : シミュレーション教育, エコーガイド下中心静脈穿刺, シミュレーター, リフレクション, ポートフォリオ 〈要旨〉

新人医師が安全に超音波ガイド下中心静脈バスキュラーアクセス（VA）穿刺術を習得するための試みとして，従 来の実践訓練に加えて新たにシミュレーション医学的手法を導入した.【対象】 2008 年 4 月〜2012 年 4 月の間に当 科において初めて超音波ガイド下中心静脈 VA 穿刺を行った卒後 2 4 年目の医師 (以下, 研修医師) 10 人.【方法】 以下の順に指導を行った. 1) 指導医による穿刺理論の講義, 2) 実際に指導医が穿刺中の動画 DVD を研修医師に配 布し，繰り返し視聴する．3）自作シミュレーターと実際に使用するカテーテルキットを用いた穿刺訓練，4）指導 医の実践を見学後, 患者で指導医とともに VA 穿刺：この際指導医は術者とともに超音波プローブを持ち, 術者に 穿刺針の進め方を指示する. 手技中の超音波画像は動画で記録する. 5) 実践後, 研修医師は指導医と一緒に録画し た超音波画像を見ながら振り返り (reflection) を行う. その後, 録画内容は CD-R にして研修医師に渡す.6)振り 返りの内容は研修医師・指導医ともに記録し (portfolio 作製), 時々俯瞰してみる. 7) 研修医師が単独で穿刺する.

8）研修医師に感想を聞く.【結果】シミュレーション学習システム導入後, 約 25 回/年の血液透析用ダブルルーメ ンカテーテル挿入および約 50 回/年の長径透析針を用いた大腿静脈反復穿刺法を超音波ガイド下に行ったが, 全例 で VA 確保に成功し，重篤な合併症も認めなかった。研修医師全員が本システムが有用であったと回答し，指導医 の感じるストレスもシステム導入により軽減した.【結論】シミュレーション医学の導入は新人医師の中心静脈 VA 穿刺技術習得における安全性を担保する上で有用と考える.

\section{Simulation program for ultrasound-guided central venous access procedural training}

Tadashi Kamata', Miyuki Ochiai', Nao Fujisawa', Yuko Kadoya', Mayumi Tomita', and Motohiro Okamura ${ }^{2}$

Department of Nephrology, Kyoto City Hospital ${ }^{1}$; Okamura Clinic ${ }^{2}$

Key words : simulation education, ultrasound-guided central venous catheterization, simulator, reflection, portfolio 〈Abstract〉

Purpose : To help novice doctors perform ultrasound-guided central venous access insertion, we introduced a novel simulation program. Participants and methods : Between April 2008 and April 2012, 10 novice doctors performed ultrasound-guided central venous access insertion in our nephrology department. The training program was as follows : 1) Lecture on the theory of ultrasound-guided puncture, 2) Repeated watching of an instructional DVD showing an instructor's performance with a patient, 3) Training using a self-made simulator and catheter kit, 4) On-the-job training with the instructor after watching the instructor's performance with patients : the instructor held an ultrasound probe together with the trainee, and directed the trainee on how to proceed for introducing the needle. The ultrasound image was recorded with a digital video recorder. 5) The trainee reflected with the instructor while watching the video after the on-the-job training. The recorded

鎌田 正 京都市立病院腎臟内科％ 604-8845 京都府京都市中京区壬生東高田町 1-2

Tadashi Kamata Tel : 075-311-5311 Fax : 075-321-6025

〔受付日：2012 年 5 月 7 日, 受理日：2012 年 8 月 22 日〕 
ultrasound video was given to the trainee as a CD-R. 6) The contents of the reflection were summarized as a portfolio by both the trainee and instructor, which was reviewed later from time to time. 7) The trainee performed the procedure by him or herself. 8) The impressions of the simulation program were obtained by interview. Results: After introducing the program, about 25 double lumen catheter insertions/year and 50 femoral central venous punctures with a long hemodialysis needle/year were all successfully performed under ultrasound guidance without serious complications. All trainees felt that the simulation program had been useful. The instructor's stress was lower than that before introducing the program. Conclusion : Introducing the simulation program was effective to increase the safety in learning the central venous catheter procedure by novice doctors.

\section{緒言}

中心静脈穿刺術において超音波の有用性が認識され るようになり，2011 年版日本透析医学会の「慢性血液 透析用バスキュラーアクセスの作製および修復に関す るガイドライン」でもダブルルーメンカテーテル留置 に際して超音波の使用が推奨されている。一方，超音 波ガイド下の中心静脈穿刺が普及するにつれて超音波 を使用しても合併症を避け得なかった報告が相次いで おり ${ }^{1,2)}$ ，充分に手技に習熟しないまま実践すると従来 の方法よりむしろ危険である可能性がある。超音波ガ イド下穿刺術は理論の理解と訓練が不可欠であるが, われわれは効率的かつ安全に技術を習得できるよう に, 従来型の実践訓練に加えてシミュレーション医学 的手法を導入したのでその概要につき報告する

\section{I．対象と方法}

研修対象は 2008 年 4 月〜2012 年 4 月の間に当科に おいて初めて超音波ガイド下中心静脈バスキュラーア クセス（vascular access：VA）穿刺を行った卒後 2〜 4 年目の医師 10 人. そのうち 5 人は腎臓内科を専攻 していたが，他の 5 人は他科専攻で研修ローテーショ ン等のため当科研修中であった。対象医師を以下“研 修医師”と呼ぶ.

\section{1. 穿刺理論の講義}

当科の超音波ガイド下 $\mathrm{VA}$ 穿刺法 ${ }^{3 \sim 6)}$ の理論につい て指導医がパソコンのプレゼンテーションソフトを用 いて講義を行った。所要時間は約 1 時間.

\section{2．実際に手技を行っている動画の視聴}

指導医が実際の患者で穿刺中の動画をDVDにして 研修医師に配布した。動画には市販の動画編集ソフト を用いて超音波画面や解説を組み込んだ（図 1).

\section{3.シミュレーターによる訓練}

Gibson らの報告 ${ }^{7)}$ を参考に超音波シミュレーターを 自作した．当科の作成法を簡単に述べる：市販のプラ スチック製粘土用ケース $(10.5 \times 20.5 \times 4.0 \mathrm{~cm})$ を購

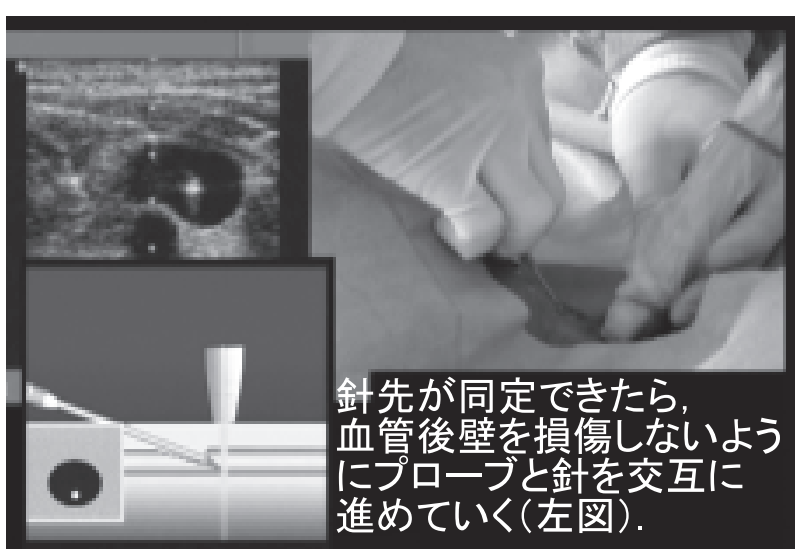

図 1 指導医が実際の症例で穿刺中の動画 DVD 動画・アニメーション・解説が組み込まれている.

入. ケース側面に $\phi 8 \mathrm{~mm}$ の穴を開け，模擬血管とし て駆血帯を 2 ～ 3 本通した．模擬血管の深さは $1 \sim 1.5$ $\mathrm{cm}$ (内頸静脈用) または $3 \mathrm{~cm}$ (大腿静脈用) とした。 粉末ゼラチン $90 \mathrm{~g}$ を熱湯 $300 \mathrm{~mL}$ に溶解した後, 水 $600 \mathrm{~mL}$ を加える。このうち約 $150 \mathrm{~mL}$ を別の容器に 移し, 薄力小麦粉 $8 \mathrm{~g}$ (内頸静脈用) または $20 \mathrm{~g}$ (大腿 静脈用）を溶かした後，もとのゼラチン溶液に戻して 攪拌する。最後に水切りネットに溶液を通してケース

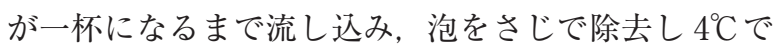
一晚冷やす．駆血帯に水道水を入れ両端を血液浄化回 路付属の使い捨てプラスチック製鉗子でクランプし た。訓練には実際の穿刺で使用する超音波装置 （iLook25，SonoSite 社）を用いた．使用後シミュレー ターは冷蔵庫 $\left(4^{\circ} \mathrm{C}\right)$ で次の使用まで保存した。

穿刺ガイド具を使わずに穿刺針先端の超音波短軸像 を描出する方法の注意点として，慣れないうちは穿刺 中に超音波画面に注意が集中すると穿刺角度が変わっ てきてしまうことがあるため，まず実際に使用する穿 刺針を使い，手元を見なくても常に穿刺角がほぼ $45^{\circ}$ となるようにスポンジを使って針の持ち方・進め方を 訓練した ${ }^{8)}$. その後，プローブを持つ手と穿刺針を持 つ手の coordination の訓練として，シミュレーターの 模擬血管のない部位に穿刺し，穿刺針先端短軸像を描 出し，針先エコーパターンが消えないように保ちなが 

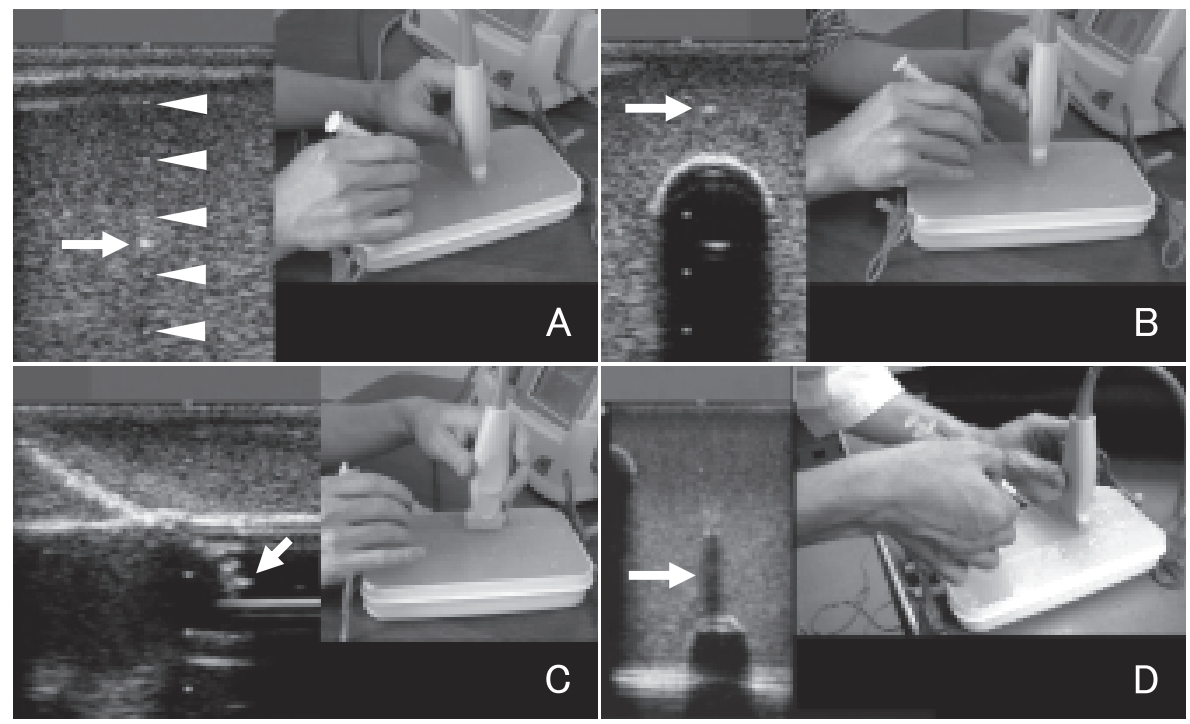

図 2 シミュレーターを使った穿刺訓練

$\mathrm{A}$ ：左右の手の coordination 訓練. 針先のエコー像（矢印）を保ちながら, 画面中央の 穿刺補助点線（矢頭）に沿って針先を進める. 図のようにプローブの角度を保って 平行移動する走査法と，プローブとシミュレーターの接点を固定してプローブを倒 していく走査法の 2 通りを練習する。

B：内頸静脈を想定したシミュレーターにおける穿刺針短軸先端像 (矢印)。意識的に 時々プローブを先行させて針先の像を消すことで針先であることを確認しながら模 擬血管前壁中央部に針先を進める.

C：模擬血管内に針先が到達した後の穿刺針長軸像．短軸像からプローブを 90 度回転 させたら，まずプローブと穿刺針と視線を一致させ，その後に画面を見てプローブ を微調整すると描出しやすい．矢印は針先．長軸像を描出することで外筒先端が血 管内に入ったかどうか確認できる.

$\mathrm{D}$ ：大腿静脈を想定したシミュレーターにおける穿刺針短軸像. シミュレーターの輝度 を高めて鼠径部の輝度に近づけているため, 音響陰影（矢印）を利用した穿刺法の 訓練に適している。実践で使用する 16 ゲージ・外筒長 $75 \mathrm{~mm}$ の透析長針を使用す る. 至適な穿刺針の把持法は術者の手の大きさ・穿刺針の長さにより異なる.

ら徐々に穿刺針を進めた（図 $2 \mathrm{~A})$ ，次にわれわれが 報告した方法に基づき32，目標血管前壁中央部に向 かって針先を誘導する訓練を行った（図 2B）。また模 擬血管内に到達後, 穿刺針の長軸像を描出した（図 2C). 大腿静脈反復穿刺法 ${ }^{5)}$ のシミュレーションも実 際に使用する血液透析用 16 ゲージ長針を用い, 穿刺 針下方に生ずる音響陰影を利用して模擬血管前壁まで 針先を誘導する練習を行った（図 2D）.

ガイドワイヤー挿入からカテーテル固定までの手技 についてはスポンジをシミュレーターとして手順を学 習した. この際, 実際に使用するダブルルーメンカ テーテルキットを用いた（図 3).

内頸静脈穿刺時にガイドワイヤーが正しく静脈内に 留置されていることを超音波で判断するためには，頸 部の解剖に熟知する必要がある ${ }^{6)}$.この訓練として, 臥位の状態で鎖骨上窩に超音波プローブをあてて腕頭 静脈・鎖骨下動脈を描出するシミュレーションを同僚 医師あるいは自分自身をモデルとして行った.

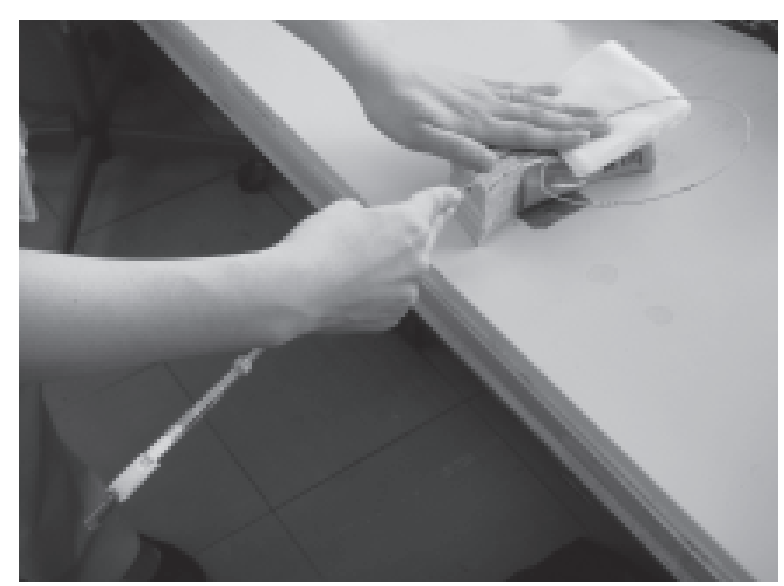

図 3 ガイドワイヤー・カテーテル操作の訓練 スポンジをテープで机に固定した簡易シミュレーター

\section{4. 指導医と一緒に実践（on-the-job training）}

指導医単独で手技を施行する症例を見学後, 研修医 師と指導医が実際の症例で内頸静脈または大腿静脈穿 刺を行った。その際, 研修医師がプローブと穿刺針を 持つが，指導医も同時にプローブを持つ（図 4).プ 


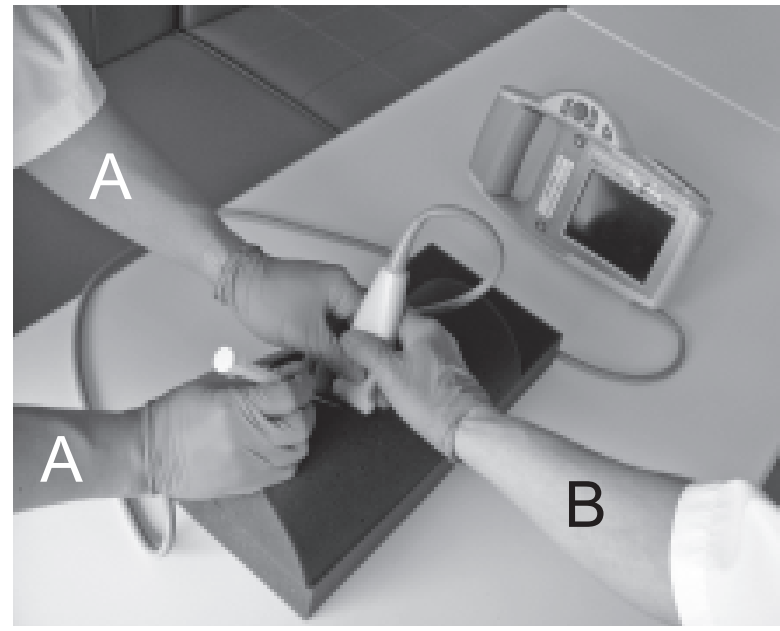

図 4 実際の症例で中心静脈穿刺施行する際の超音波ブ ローブ把持法のイメージ

$A$ : 研修医師 $B$ : 指導医

ローブの走査は基本的に指導医が行い，研修医師はプ ローブの動きを体感する。穿刺針は指導医の指示に 従って研修医師が 2 $3 \mathrm{~mm}$ ずつ進めた。手技中の超 音波画像は市販の録画機（DVR-2100，アジアコープ インターナショナルリミテッド社）を超音波装置のビ デオ出力端子に接続して動画として記録した. 原則と して実践前日あるいは実践直前にはウォーミングアッ プとしてシミュレーションを行った上で実践に臨ん だ。

5. 振り返り (reflection)

患者での手技終了後, 施行当日中に研修医師と指導 医で記録した超音波画像の動画を見ながら，良かった 点・悪かった点や次回いかにフィードバックするかに ついてディスカッションを行った，その後，動画は CD-Rにして研修医師に渡し, 単独でさらに振り返り がしやすいようにした.

\section{6. 振り返りの内容の記録（portfolio 作製）}

研修医師・指導医が各々 reflection の内容を記録し, 時系列に沿って保存した. 形式は紙でもデジタルファ イルでもどちらでも可としたが，前者の場合は一つの ファイルに閉じることで一元的に管理し，次の実践の 直前に容易に復習できるようにした，後者の場合は印 刷して俯瞰しやすいようにした。

\section{7. 研修医師への感想の聞き取り調査}

当科での研修を終える時に研修医師にシミュレー ション学習システムについての感想の聞き取り調査を 行った.

\section{II. 結果}

手技模範を示すため一部の症例は指導医が単独で手 技を施行したが，基本的に研修医師が順番に指導医同 席の下施行した。 2008 年 4 月から 2012 年 4 月にかけ て約 25 回/年の血液透析用ダブルルーメンカテーテル 留置および約 50 回/年の長径透析針を用いた大腿静脈 反復穿刺を超音波ガイド下に行ったが, 全例で VA 確 保に成功し，重篤な合併症も認めなかった。研修医師 の感想は全員が当科のシミュレーション学習システム を有用と感じたとの回答であった．個別の感想として は, “針先がわかるので安心”, “訓練により穿刺角度が 安定した”，“実践する前に器材に慣れているので良 い”, “初めての実践手技で成功し達成感が得られた” といった肯定的なものがほとんどであったが, “シミュ レーターがもっとリアルだといい”といった意見も あった，指導医側も，手技実践の場で最も重要な超音 波プローブ走查が自分のコントロール下にあるため, ブラインドで穿刺を行っていた頃に比較すると安心し て指導できた．また，複数の研修医師が同じ技術的問 題を繰り返す現象がみられた，具体例として“内筒・ 外筒部の境界（術者に近い方）がわかりにくい穿刺針 を使用する際，内筒を抜去しょうとして誤って内筒と シリンジを分離してしまう”, “カテーテルを挿入する 際に内部のスタイレットが緩んでずれているのに気づ かないため, カテーテルの挿入抵抗が大きくなり挿入 できない”, “カテーテル挿入後スタイレットを抜去し てインナーカテーテルを挿入する際に, 止血のためカ テーテルを指で圧迫して閉鎖すべき部位を間違え不要 な失血をする”などである。これらに対しては実践前 に指導医が各研修医師の portfolio を確認することで 要注意の手技ステップがあらかじめわかるため, 指導 医のストレスが軽減された。また，同じ問題が繰り返 される場合は研修医師が手技直前に portfolioの見直 しやシミュレーターでウォーミングアップをしていな い場合にみられたが, 同時に使用器材の構造上の問題 であることもあり，器材の製造元に改善の要望を出す ことで対応を得られたケースもあった。

\section{III. 考 察}

わが国でもシミュレーション学習法は運輸会社・金 融会社・電力会社・軍事関係などでは当然の存在となっ ているが, 医療への導入については救急・看護領域で はかなり進んできているものの, 医師教育の観点から 
はまだ充分とはいえない.その理由の一つに，多忙な 指導医が教育に労力を費やしても病院経営サイドから 評価されないことが多いことがあげられよう．当科で は年間約 25 回の透析用ダブルルーメンカテーテル留 置手技を施行しているが，手技を行うのは医師 3〜4 人である。したがって医師 1 人あたり約 1.5〜2 か月 に 1 回の施行頻度となる. 当科で行っている超音波ガ イド下穿刺ではプローブを積極的に走査して針先位置 を特定するため ${ }^{3 \sim 5)}$, 虚脱した中心静脈や深部末梢静 脈でも確実な穿刺が可能であるが，その習得には一定 の訓練を要する。ふだんから何らかのトレーニングを しなければ研修医師のスキルアップはおろか指導医の スキル維持すら困難なことから, 必要に迫られる形で シミュレーション学習システムを導入した。 また，超 音波ガイド下穿刺は従来の方法に比べて患者側の条件 による影響が少ないためシミュレーション訓練に適し ている.

マルチメディアの活用・シミュレーター訓練・実践 訓練・reflection・portfolio を骨子とした当科の中心静 脈 VA 穿刺シミュレーションシステムを図 5 にまと めた。 まず講義であるが，研修医師がスムーズにト レーニングに入れるように穿刺理論を中心にアニメー ションや動画を多用した講義を指導医がプレゼンテー ションソフトを用いて行っている，また，指導医が穿 刺実践中の動画をDVDにして研修医師に渡すこと で，多忙な研修医師が空いた時間にいつでも，繰り返 し学習ができるよう配慮した。. 次にシミュレーターで の訓練であるが, 当科ではシミュレーターを自作して いる. 市販の超音波シミュレーターも利用可能である が，非常に高価である上に耐久性にそしく，熱心に練 習すると水漏れし, 刺入痕と穿刺針のエコー像との区 別がつきにくくなるため短期間で使用不能となる。そ の点, われわれの作製している超音波シミュレーター は実時間 10 分で作り直すことができ, 使用後 $4{ }^{\circ} \mathrm{C} て ゙$ 保 存すれば最長 1 週間程度使用可能でランニングコスト 的に有利である。研修医師からもっとリアルなシミュ レーターを要望する声もあったが, 模擬血管の弾性な ど改良の余地はあるものの自作シミュレーターは hand-eye coordination の基礎訓練用として極めて有 効である．高価なシミュレーターが安価なものより必 ずしも優れているとは限らないことは Alessi の論文 ${ }^{9)}$ や, 各地の医学部のスキルスラボ (臨床技能研修室) においてハイテクシミュレーターが倉庫で埃をかぶっ ていることからもわかる。自作シミュレーターには ソーセージ10) やゲル状の掃除用具 ${ }^{11}$ を使用した報告も あるが, 当科のものは小麦粉の量を増減することでエ

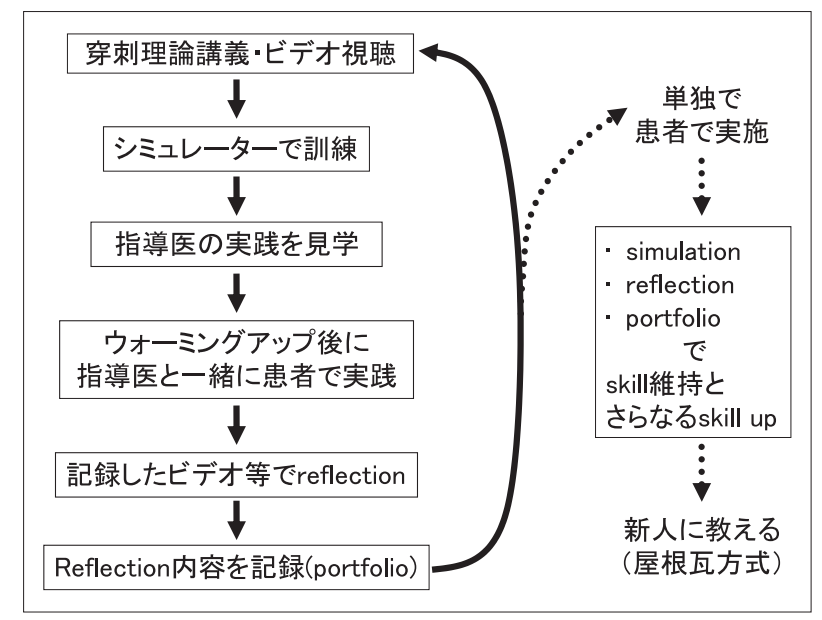

図 5 穿刺トレーニング概要

初めは上記実線矢印のステップを繰り返し, 一定のレベル に到達したら単独で実施し(破線矢印), その後もシミュ レーションで skill 維持と skill up を図る.

コー輝度を変えることができるため, 内頸静脈や大腿 静脈などそれぞれの状況設定に応じた調整が可能であ る.また, 当初超音波ガイド手技のみをシミュレー ション訓練していたが, 使い捨て式インナーカテーテ ルを持つ特殊な透析用ダブルルーメンカテーテルを採 用していることも影響して, 研修医師が実践の場で超 音波ガイド以外のステップでつまずくことが多発し た.このためガイドワイヤーやダイレーター・カテー テル本体の操作もシミュレーターで訓練を行うように したところ, 改善がみられた。 シミュレーターはスポ ンジを机に固定しただけの極めて簡易なものではある が，実際に使用するカテーテルキットを用いていつで も繰り返し練習することができるため, 留置手順が身 につき, カテーテルキット固有の構造上の “㾕” も理 解できる. 実践直前のウォーミングアップとしても有 用である。 また，血液透析用ダブルルーメンカテーテ ルは穿刺針とダイレーターの直径の差が一般のカテー テルに比べて大きいため, ダイレーター挿入前に超音 波で正しくガイドワイヤーが静脈内に留置されている ことを確認することが安全上重要と考えられる ${ }^{6)}$. ガ イドワイヤー位置確認の成否は患者側の血管の視認性 の影響を受けるため, シミュレーターではなく, 自分 あるいは同僚医師の頸部の血管系を描出し解剖に慣れ ておくようにした。

生体組織はエコー輝度が比較的不均一のため, 均一 なエコー輝度を持つシミュレーターよりも穿刺針先端 の視認性が不良である。さらに，呼吸とともに形を変 え，穿刺針を刺入しょうとすると容易に虚脱する中心 静脈の前壁のみを穿刺する感覚は市販のシミュレー ターでも再現が困難であり, 実践で養う必要がある。 
このため，シミュレーターで基碟技術を固め，指導医 の実践を見学した後，実際の症例で指導医とともに手 技の施行（on-the-job training）に臨む. Kahol $ら^{12)}$ は ベテラン外科医でも腹腔鏡手術の前に 15 分シミュ レーターでウォーミングアップすると効果があると報 告しており，当科でも時間的に余裕があれば害践直前 に改めてシミュレーションを行うよう指導している. On-the-job training では超音波ガイド下穿刺の際に 最も難しいプローブの走查を指導医がリードし, 最も 重要な情報である超音波画像を研修医師・指導医が共 有するため，その安全性は高い，研修医師の技術向上 にあわせて指導医がプローブ走査アシストをウィーニ ングすることで, 研修医師の単独施行へのスムーズな 移行が可能であった．超音波画面は安価な市販のデジ タルビデオ録画機で記録し，実践後の reflection 時に 供覧することで学習効果を高めている. Reflection と は 1930 年代に米国の思想家 John Deweyによって提 唱された成人教育理論で，“振り返り”や“省察”と訳 される，学習者が行動の結果について主体的に考える 学習法であり, 単なる成功体験の反復という受動型学 習とは一線を画している，Kolb ${ }^{13)}$ はさらに“経験 $\rightarrow$ 振 り返り $\rightarrow$ 概念化 $\rightarrow$ 実践 $\rightarrow$ 経験 $\rightarrow \ldots$...という終わりの ない経験学習モデルを提唱した（図 6). Portfolio と は“振り返りを通して獲得した学習成果をみることが できる記録集”であり，1990 年代後半にわが国に導入 され，現在では小学校教育から大学院教育まで浸透し ている ${ }^{14)}$. Portfolio の内容は文字情報・図・写真・動 画などさまざまな形式が可能だが，バラバラではなく 一元化して保存しておくことが重要であり, 時々俯瞰 してみることで Kolb のモデルの “概念化”が促進さ れる，その際，portfolioのうち重要なものを抽出して まとめておくと(凝縮ポートフォリオ $\left.{ }^{15}\right)$, 実践の直前 に見直しやすい. On-the-job training で明らかに なった自己の課題に対してさらにシミュレーションに よる学習を積むという反復は非常に有効であるが，長 期間実践する機会がない場合はシミュレーションによ り技術を維持する必要がある. Stefanidis $ら^{16)}$ は腹垫 鏡のシミュレーションを 3 か月ごとに行うことで技術 レベルが維持できると報告したが, 彼らは最終評価を シミュレーターで行っている，極めてストレスの高い 実践の場で侵襲的手技をスムーズに遂行するには，よ り頻繁にシミュレーション訓練を行う方が望ましいと 思われる。

シミュレーション訓練に㧍いて “研修医師が安全に VA 穿刺を実践できたか?” という点は重要なアウト カムであり，その評価のためにはランダム化比較試験

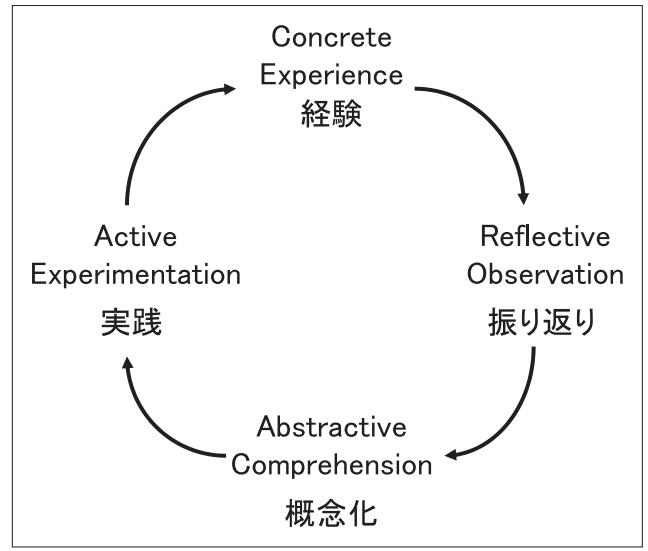

図 6 Kolb の経験学習モデル ${ }^{13)}$

経験をさまざまな観点から内省し（振り返り）, そこで得られた気づきを基に他の状況でも応用 できるような独自の理論を構築し (概念化), そ の理論を新たな状況で試行する (実践). そこ で得られた経験をさらに振り返る……というサ イクルを回すことで, 経験が知識に変換される.

が望ましい．われわれはそうした評価法を行っておら ず, 本研究の限界ともいえるが, 最近 Cook らはメ夕 解析でシミュレーション訓練の有効性を示し, “もは やシミュレーションの有効性を示す研究よりも，い つ・いかにコスト面も含めて効率的にシミュレーショ ン訓練を行うべきかを明らかにする研究の方が重要で ある”と述べている ${ }^{17}$. 研修医師をシミュレーション 訓練したグループとしないグループに分けて穿刺成功 率や合併症発生率を比較することは医療安全に対する 要求の高まりの中, 倫理的な問題も危惧される. 既述 したごとく，研修医師や指導医の印象は概称良好であ り, シミュレーション学習システム導入後に透析 VA 穿刺において重篤な合併症を認めていないことから も, 本システムの有効性が示唆される. 日本透析医学 会雑誌データベースで技能的なシミュレーション学習 に関する報告を検索したが学会発表のみであり，論文 では該当するものはなかった，当科で研修した医師に は他院に赴任後に超音波穿刺の指導的立場になってい る医師もおり，われわれの試みを報告することは意義 あるものと考えた。また当科での中心静脈穿刺の実践 は卒後 2 年目以降に行っているが，これは当院内の規 定に従ったものであり 1 年目の施行も可能と考える.

危険を伴う侵襲的な手技を安全に行うアプローチと しては, シミュレーション学習システムの構築以外に, 専任医師のみが集中して行うというものがある。実際 に血液透析用カテーテル留置を麻酔科が行っている施 設もあり, 安全性・効率上のメリットがあるが, 24 時 間常にカテーテル留置を請け負ってくれる医師が身近 にいるとは限らない。一方，新規にシステムを立ち上 
げる場合には，確かな知識・技術を持ったインストラ クターが必須である。まずインストラクター役になる 医師を決め, シミュレーション学習法や学会・企業主 催のハンズオン・セミナーを利用しながら習熟するま で手技を専任的に行い，その後インストラクターが他 の医師を指導すること（いわゆる屋根瓦方式）が現実 的と思われる.

\section{結語}

成人学習の専門家である Donald Schön は, “真の professional というのは, reflection しながら自分の到 達課題に向かって成長し続ける人である”と述べてい $ろ^{18)}$. 透析医療の技能習得において, 実践訓練とシ ミュレーション医学的手法を組み合わせた学習法は reflection を支援するツールとして極めて有用と思わ れる。

本論文の要旨は第 57 回日本透析医学会総会にて発表 した.

\section{文献}

1）楠本 剛, 岩下耕平, 比嘉裕樹, 香取 清, 仁田原慶 一, 比嘉和夫：超音波ガイド下の内頸静脈穿刺での合 併症 3 症例の報告. 麻酔 $58: 760-761,2009$

2) Blaivas $M:$ Video analysis of accidental arterial cannulation with dynamic ultrasound guidance for central venous access. J Ultrasound Med 28 : 12391244, 2009

3）鎌田 正, 落合美由希, 藤澤奈央, 門屋佑子, 八城正 知：超音波ガイド下血管穿刺における穿刺針先端描出 法の検討．京都市立病院紀要 30(2)：16-20, 2010

4）鎌田 正, 落合美由希, 大崎啓介, 藤澤奈央, 門屋佑 子, 八城正知：新たな血液透析返血経路としての超音 波ガイド下 brachial vein 穿刺法の検討. 透析会誌 $44: 237-243,2011$

5）鎌田 正, 朱 星華, 落合美由希, 藤澤奈央, 門屋佑 子, 八城正知：超音波ガイド下に大腿静脈反復穿刺を
行い血液浄化法を施行した 16 例の検討。透析会誌 $45: 241-246,2012$

6）鎌田 正, 落合美由希, 藤澤奈央, 門屋佑子：超音波 ガイド下内頸静脈ダブルルーメンカテーテル挿入時に おけるガイドワイヤー視認性の検討. 透析会誌 45 : 475-482, 2012

7) Gibson RN, Gibson KI : A home-made phantom for learning ultrasound-guided invasive techniques. Australas Radiol $39: 356-357,1995$

8）浅尾高行：超音波ガイド下中心静脈カテーテル挿入ト レーニング. p33-34, 中外医学社, 東京, 2011

9) Alessi S: Fidelity in the design of intructional simulations. J Comput-Base Instr $15:$ 40-47, 1988

10) Wells M, Goldstein L, The polony phantom : A costeffective aid for teaching emergency ultrasound procedures. Int J Emerg Med 3 : 115-118, 2010

11）浅尾高行：超音波ガイド下中心静脈カテーテル挿入ト レーニング. p133, 中外医学社, 東京, 2011

12) Kahol K, Satava RM, Ferrara J, Smith ML : Effect of short-term pretrial practice on surgical proficiency in simulated environments : a randomized trial of the “preoperative warm-up" effect. J Am Coll Surg 208 : 255-268, 2009

13) Kolb DA : Experiential Learning : Experience as the Source of Learning and Development. p20-34, Prentice Hall PTR, New Jersey, 1984

14）岡田 満: 医学教育におけるポートフォリオ. 近畿大 医誌 $35: 77-82,2010$

15）鈴木敏恵 : ポートフォリオとプロジェクト学習. p11, 医学書院, 東京, 2010

16) Stefanidis D, Korndorffer JR Jr, Markley S, Sierra R, Scott DJ : Proficiency maintenance : impact of ongoing simulator training on laparoscopic skill retention. J Am Coll Surg 202 : 599-603, 2006

17) Cook DA, Hatala R, Brydges R, Zendejas B, Szostek JH, Wang AT, Erwin PJ, Hamstra SJ : Technologyenhanced simulation for health professions education : a systematic review and meta-analysis. JAMA $306: 978-988,2011$

18）藤崎和彦：シミュレーション医学教育入門. p8, 篠原 出版新社, 東京, 2011 